\title{
熱画像を用いた建物外表面からの顕熱流量の解析 \\ ANALYSIS OF THE SENSIBLE HEAT FLUX FROM THE EXTERNAL SURFACE OF A BUILDING USING THERMOGRAPHY
}

\author{
梅干野 苌*, 浅 野 耕 一**, 金 丸 剛 久*** \\ Akira HOYANO, Kohichi ASANO and Takehisa KANAMARU
}

\begin{abstract}
In this study, the distribution of surface temperature on the surface of two buildings was measured using a thermal infrared camera. Two buildings having different characteristics were selected and surveyed in summer and winter for comparison. with difference of weather conditions, especially solar radiation. Using time sequential thermography, the heat characteristics of each building were investigated and the surface temperature of each element of the building, which was classificd according to temperature, shape, matterial and position, was obtained throughout the day. The sensible heat flux from whole observed building surfaces were calculated based on these measurements and the areas of all elements which was obtained from a blue print of the buildings.
\end{abstract}

Keywords : thermal infrared camera, thermography, external building surface, surface temperature, sensible heat flux 赤外線放射カメラ，熱画像，建物の外表面，表面温度，顕熱流量

\section{1.はじめに}

建物外表面の熱收支特性と屋外の微気候や都市気侯との関連 性を検討することは，熟環境の観点から快適な都市を計画する 上で重要である。しかし, 都市気候の数值計算モデルに対し，建 物の空間形態の細部をどの程度まで考慮すべきかについては, 実用的な指針が得られるに到っていない。その大きな要因の一 つは，建物外表面の熱収支に対する実態の解明が，その非常に 複雑な様相が故に，十分に進行していないためと考えられる。建 物外表面の熱収支が複雑な様相を示すのは，建物外部における 多様な空間形態や材料の熱的特性が，外表面の日射吸収や天空 二の放射冷却，対向面との放射授受，近傍の気流分布等の外界 条件と深い関わりを持ち, 屋内における冷暖房も大きく影響し ているからである。

筆者らは既に，都市スケールでの地表面の熱収支を分析する ため，単純な矩形の建物を都市気候の数值計算モデルに組み込 む陚みを行っている”。また，航空機よりスキャナーを用いて地 上を鉛直下向き及び斜め下向きに見ることで，建物全表面の温 度分布を捕らえ, GISデータを併用することで, 地域レベルでの 顕熱流量を試算している2) 3)。その結果の一つとして, 同じ R C 造建物地区又は木造建物地区どうしを比較しても，個体差が大 きく現れることが確認された。個々の建物に対する材料や形態 の差異が反映された結果と言える。しかし，複雑な形態や材料 構成の建物における外表面からの放熱特性について詳細な実測 調查結果の報告はほとんどみあたらない。そこで本報では，多 様な形態や材料を有する建物からの顕熱流量の特性について実 測調查を行う。調査結果は, 都市気候の数值計算モデルに組み
込むべき建物モデルを検討する上での基礎資料となる。

顕熱流量の計測手法には, 斉藤らのSAT計4や, 松尾らによる 対流熱伝達率測定器の試作例 ${ }^{5}$ が挙げられる。これらの手法は, 顕熱流量を直接求められる利点を持つ。しかし，外表面上の一 部分からの顕熱流量を求める装置であるため, これらを用いて 建物全表面からの顕熱流量を求めることは困難である。そこで, 面的情報を得られる赤外線放射カメラに着目する。筆者らは既 に，赤外湶放射カメラを用いた計測手法について検討してきた ”。本報ではこれらの知見をもとに建物全表面の温度分布を計測 し，それらの結果から顕熱流量を算出する。

\section{2. 実測概要}

\section{1. 実測対象建物の概要}

測定対象には研究の第 1 歩として，材料構成や形態の全く異 なる建物を 2 件選定した。これらの建物の共通点は外表面の形 態や材料構成によるパッシブな手法で，屋根や外壁すなわち外 表面の熱収支を調節することが設計の過程で考慮されているこ とである。特に日射調整の工夫が全体的に取り入れられている。 N建物は大阪市内の市街地にある実験集合住宅(地下 1 階, 地 上 6 階建て）で，全 18 住戸から構成される。構造体は，鉄筋コ ンクリートの柱梁構造で表面は打ち放しである（以下，スケル トンと呼ぶ)。屋根・壁等の主な材料構成を付表 1 に示す。この 建物は景観向上のため，中庭や屋上が植栽で覆われている。ま た，立面の各階には立体外廊下が設けられている。周囲には高 層建築も見られるが, ほとんどが 2 階建ての木造家屋である。図
* 東京工業大学 教授. 工博

** 東京工業大学 大学院生・修士 (工学)

*** 東京工業大学 大学院生
Prof , Tokyo Institute of Technology, Dr. Eng.

Graduate Student, Tokyo Institute of Technology, M. Eng.

Graduate Student, Tokyo Institute of Technology 
1 (a)にN建物の外観，図 3 に 5 階平面図を示す。

$\mathrm{F}$ 建物は，福島県いわき市にある住宅展示場内の木造 2 階建 てのモデルハウスである。南側には８階建てのビル，北側は広 場がある。屋根面の芝生や自然換気用の天空・床下ピットが特 徴的である。屋根。壁等の主な材料構成を付表 2 に示す。夏季は 1 階塞務室 (図 2 参照) のみ冷房運転し，冬季は温風と床暖房を 併用している。図 1 (b)にF 建物の外観, 図 4 に断面図を示す。

\section{2. 熱画像の収録条件}

熱画像の収録には，2台の赤外線放射カメラを用いた" ${ }^{\# 。 1 ~}$ 台は固定した状態での俯瞰撮影に用い，もう 1 台は俯瞰撮影て 死角となる部位 (軒睃，天井等) の移動計測に用いた。俯瞰撮影 は建物の表面温度变化と日射や気温変動との詳細な対応を観測 するためで，1 分間隔で 24 時間以上行った。図 2 に実際に行っ た俯瞰撮影の概念図を示す。

移動計測の時間帯は, 外気温が最低となる日の出時の直前, 表 面温度が全体的に最も高くなる正午前後，躯体の蓄熱量の違い による温度差が表れ始める日没直後に行った（表 1 ）。日の出。 日没時刻は実測現場での太陽の出没時刻を採用した。移動計测 は，1時間以内に完了するようにした。移動計測対象のほとん どは日中に日影となるため温度変化が緩やかであり, 計測結果 の時刻補正は行っていない。図 5 にデータに用いた測定日の外 気温・水平面全天日射量及び風速を示す。

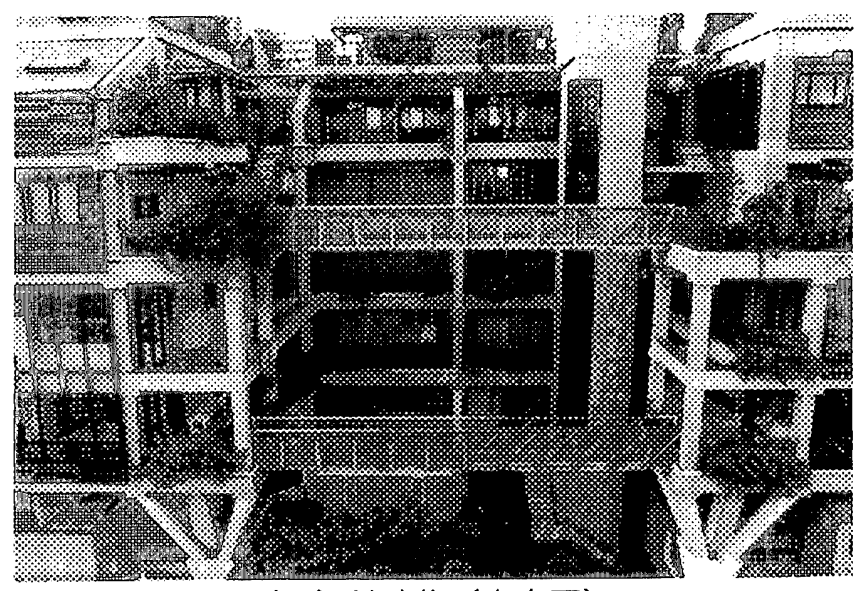

( a ) $\mathrm{N}$ 建物（南立面）

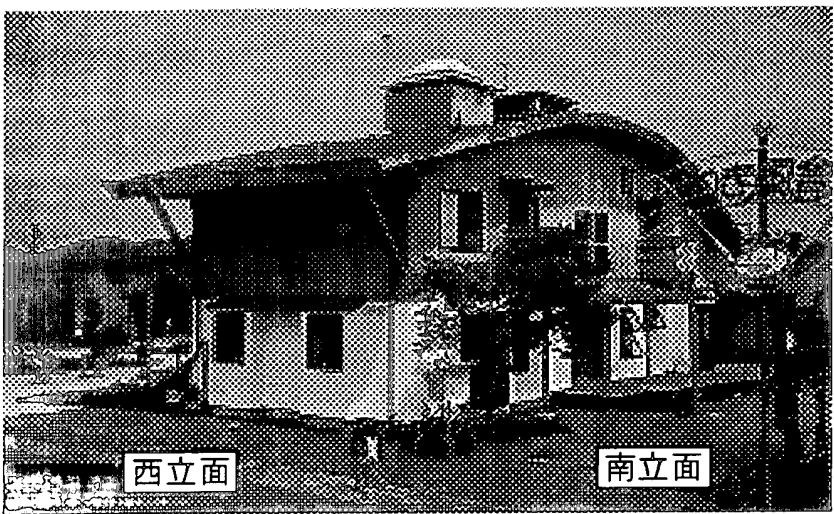

(b) $F$ 建物

図 1 測定対象とする建物の外観 (a) N 建物

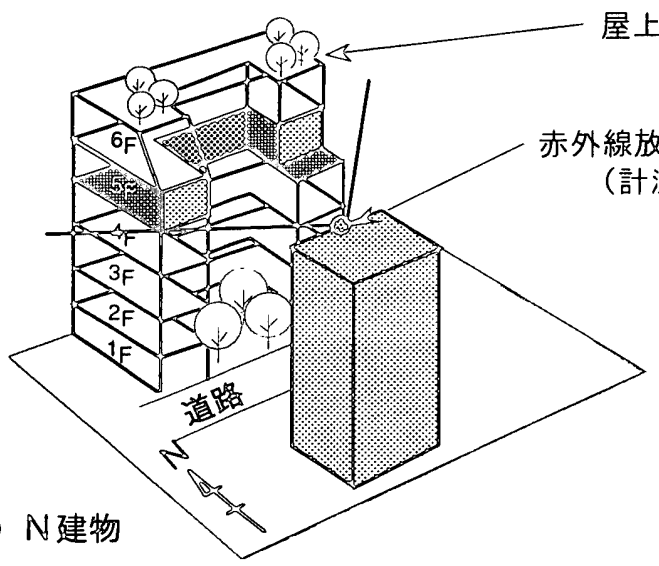

屋上植栽

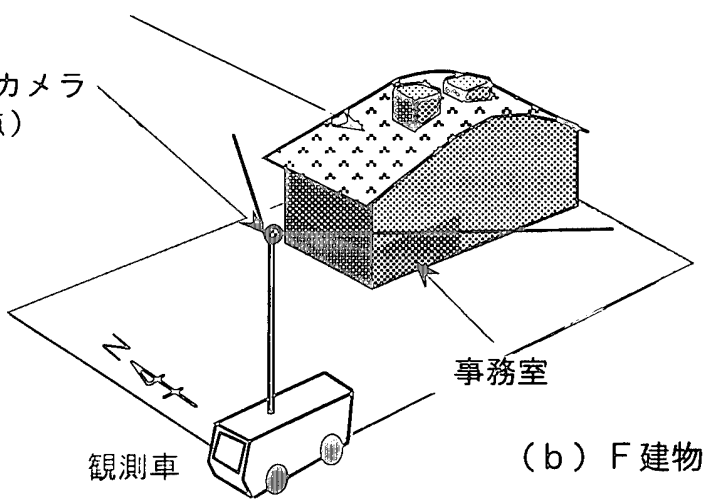

図 2 実測の概念図（熱画像の俯瞰撮影）

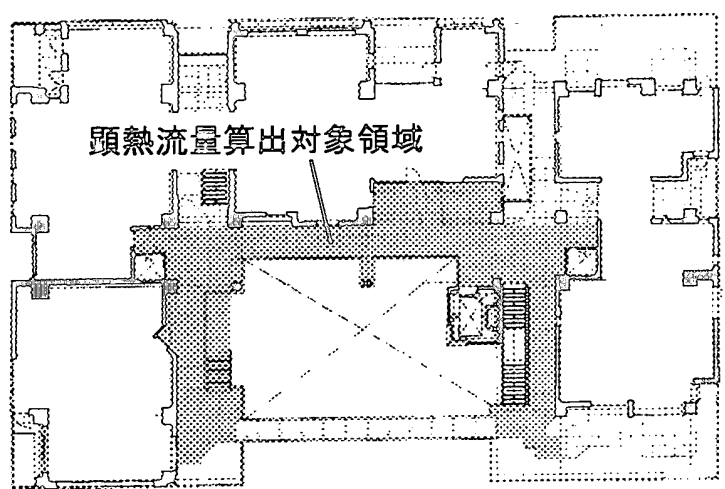

図 3 N建物の 5 階平面図

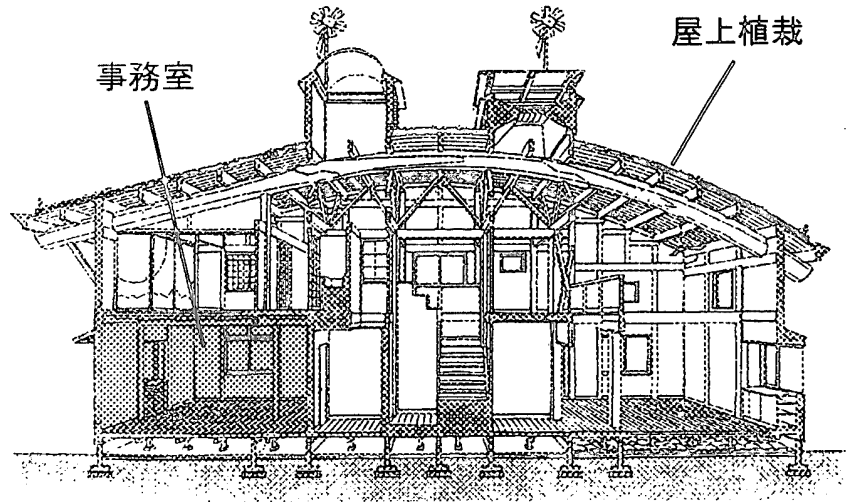

図4F建物の铒面図 


\section{（イ） N建物における熱画像収録条件}

俯瞰撮影は, 立体外廊下を有する南立面が一望できるよう, 道 路を挟み向かい側の 5 階建てのビルの屋上から行った。顕熱流 量の算出は，立体外廊下の日射調整効果等を把握するため，中 庭に面した 5 階全表面（4 階天井面〜 6 階床面）を対象として 行う（図 3)。解析対象日の気象条件は, 夏季の場合, 気温が最 高 34.9 ・最低 $27.2 \cdot$ 平均 $30.2^{\circ} \mathrm{C}$, 屋上風速は夕方に約 $7 \mathrm{~m} / \mathrm{s}$ 近く まで達する場合もあるが，日中から夜間にかけては約 $3 \mathrm{~m} / \mathrm{s}$ 前 後, 樑夜から明け方にかけては約 $1 \mathrm{~m} / \mathrm{s}$ 前後であった。冬季の場 合は気温が最高 12.1 ・最低 $1.4 \cdot$ 平均 $6.7^{\circ} \mathrm{C}$ で, 屋上風速は日中か

表 1 移動計測を行った時間帯

\begin{tabular}{|c|c|c|c|c|c|}
\hline & \multirow{2}{*}{ 測 } & \multirow{2}{*}{ 定，日 } & \multirow[b]{2}{*}{ 日の出 } & \multicolumn{2}{|c|}{ 計 測 時 間 帯 } \\
\hline & & & & 正 午 & 没 \\
\hline \multirow{2}{*}{ N建物 } & 夏季 & 1995.8 .9 & $4: 00 \sim 5: 00$ & $12: 00 \sim 13: 00$ & $19: 00 \sim 20: 00$ \\
\hline & 冬季 & 1996.1 .13 & $6: 00 \sim 7: 00$ & $12: 00 \sim 13: 00$ & $18: 00 \sim 19: 00$ \\
\hline \multirow{2}{*}{ F 建物 } & 夏季 & 1995.7 .28 & $4: 30 \sim 5: 00$ & $12: 30 \sim 13: 00$ & $19: 00 \sim 19: 30$ \\
\hline & 冬季 & 1996.2.7 & $6: 30 \sim 7: 00$ & $12: 30 \sim 13: 00$ & $18: 30 \sim 19: 00$ \\
\hline
\end{tabular}
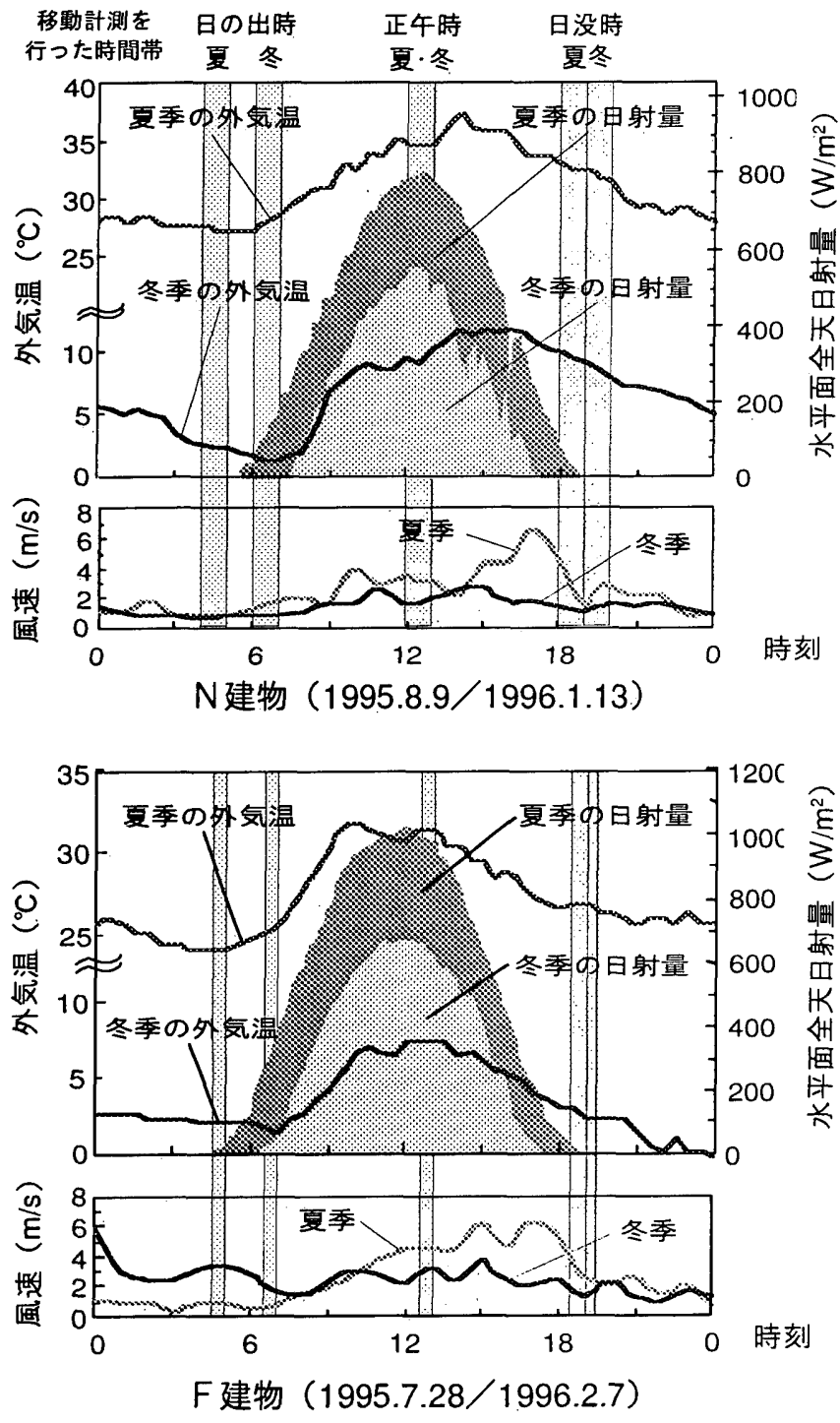

図 5 解析対象日の気象条件
ら夜間にかけては約 $2 \mathrm{~m} / \mathrm{s}$ 前後, 樑夜から明け方にかけては約 1 $\mathrm{m} / \mathrm{s}$ 前後であった。屋内気温は, 夏季は自然室温で $28 \sim 31^{\circ} \mathrm{C}$, 冬 季は終日暖房運転を行い $20^{\circ} \mathrm{C}$ 前後に保たれていた。

（口） $\mathrm{F}$ 建物における等画像収録条件

俯瞰撮影は, 建物の前に設置した観測車の伸縮ポール先端(高 さ $7 \mathrm{~m}$ ）より，屋根面・南立面・西立面が一望できるように行っ た。撮影位置は日射による温度変化が大きいこと等を考慮して 決定した。顕熱流量の算出は建物の全表面を対象とする。解析 対象日の気象条件は, 夏季の場合, 気温が最高 $31.4 \cdot$ 最低 23.9 ・ 平均 $27.4^{\circ} \mathrm{C}$, 屋上風速は夕方に約 $6 \mathrm{~m} / \mathrm{s}$ 近くまで達寸る場合もあ るが，日中は約 $4 \sim 5 \mathrm{~m} / \mathrm{s}$ ，夜間は約 $1 \sim 2 \mathrm{~m} / \mathrm{s}$ であった。冬季

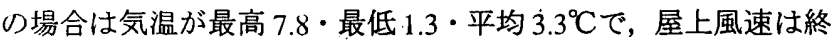
日約 $1 \sim 3 \mathrm{~m} / \mathrm{s}$ であった。 $\mathrm{F}$ 建物の空間構成は, 一階の西側にあ る事務室以外は，ほぼ全ての部屋が空間的に連続しており（図 4 ), 従って屋内気温も 2 種類に大別される。夏季は一階事務室 (図 $2 \mathrm{~b}$ 参照) で日中に冷房運転を行い $28^{\circ} \mathrm{C}$ 前後, それ以外の部

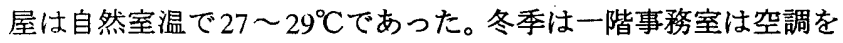
しており $24^{\circ} \mathrm{C}$ 前後に, その他では床暖房を行い $23 \sim 25^{\circ} \mathrm{C}$ 前後に 保たれていた。

\section{3. マルチテンポラル熱画像による考察}

\section{1. マルチテンポラル熱画像の作成方法}

建物の外表面温度分布の日変化，すなわち 3 つの時刻におけ る熱画像を一枚の RGB 画像に合成した。本報ではこれをマルチ テンポラル熱画像（MT熱画像）と呼ぶ。この画像により，外表 面温度分布の日変化の特徴を，建物や季節の間で視覚的に比較 する事が容易となる。MT熱画像の作成は以下の手順に従った。 1) 日の出・正午・日没後の各熱画像のヒストグラムを作成する。 2 ）ヒストグラムの累積比率を求め，5～95\% を採用する。

3 ）温度スケールの中央值を外気温とし，それに応じて温度表 示範囲を決定する。

4）早朝を青, 正午を赤, 日没後を緑とし, 各熱画像を単色ス ケールで表現する。スケールは明度が大きいほど高温とする(具 体的な時刻は図 $8 \cdot 9$ の注釈を参照)。

5） 4 で作成した 3 色の画像を加算混合する。

図6に温度スケールの決定方法をヒストグラムで示した。図 7 は参考までに上記の手順 3 を省いて作成した MT 熱画像であ る。この一枚の画像より, 日の出・正午・日没時の放射温度分布 を把挃できるが，放熱状況を知ることはできない。手順 3 で温 度スケールの中央值を外気温に設定することで，建物外表面の 温度が外気温より高いか低いか, すなわち放熱か吸熱状態かを， 色度より判断できる。図 8. はN建物の夏・冬におけるMT熱画像, 図 9 はF 建物の夏・冬における MT熱画像である。図 9 の右下に 放熱状況を判断するためのカラースケールを示す拄 2 。

\subsection{MT 熱画像に対する考察}

\section{（イ） N建物の MT熱画像に対する考察}

夏季と冬季のMT熱画像を比較すると, 夏季は全体的に色度が 低く，冬季は全体的に色度が高い。この季節間の違いの主な要 


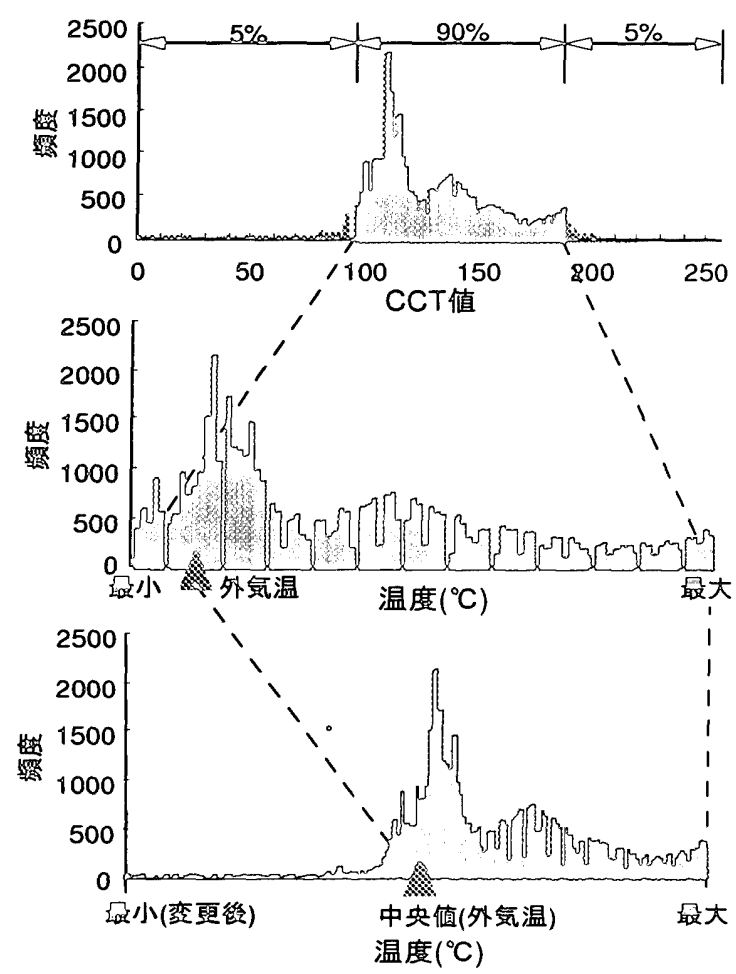

図6MT熱画像における温度スケールの決定方法 （本文中の手順 $1 \sim 3$ に対応）

因には，㨁逹日射の入射状況や暖房運転の有無が挙げられる。

聚抙の画像で赤い部分のほとんどが，日除けが設けられてい ない立面である。これらは日中に直達日射を受けて外気温より 高温になるが，夜間は天空への放射により冷却される部位であ る。立体外廊下的部は青系統の色を示している。日中に直達日 射を受けず, 外気温と同等かそれ以下の表面温度に留まるが, 夜 間の天空への放射による椧却が促進されず，日の出時には外気 温よ゙り高くなったことを意哧している。スケルトンは全体的に 白に近い。コンクリート打ち放しのため，日中に受けた日射熱 が夜間も蓄熟されているためである。

冬抙は立体外廊下内部を含む大部分が淡色である。これは低 い高度からの直達日射を受けて受熱日射量が增大し, 更に暖房 䢔転の影留も加わり，終日に渡り放熱する結果となった事を意 䊅する。立体外廊下内部が熒青色を示寸要因は，直達日射のあ たらない部分が依然と存在することや，夏季と同様，夜間の天 空への放射による冷却がほとんど行われないことである。

（口） F 建物の MT 熱画像に対する考察

夏㨻は 1 階西立面が涱い緑，それ以外の部位は漕い赤を示し た。一階西側の牽势室の部分が灙い緑を示したのは，日中は日 影で且つ冷房通転の影偲で低温にあり，夕方の西日で高温化す るが, 日没時には再び外気温との温度差が縮まったためである。 また，澱い赤を示した部位は木の板張りの外壁面であり，比較 的熟容盈が低く，日中は高温化するが夜間まで蓄熱されにくい。

これに対して冬季は屋根面を除くほとんど全ての部位が白に 近く, 終日に渡り放熱していたことが分かる。特に天空や軒裹。 開口部・布基硌等が淡青である事から，暖房運転の熱が屋内か ら外に流れている現鰁が読みとれる。次章以降では，本章で考 察した現象を定量化し，建物の放熱現象の実態を明らかにする。

\section{4. 建物外表面の分割と温度抽出}

\section{1. 建物外表面の分割方法}

建物外表面からの顕熱流暴と，建物の材料。形態との関保を 考察するため, 外表面を分割して部位毎に表面温度を抽出する。 建物外表面をどの程度詳細に分割して扱らかは，各部位の形態。 材料等から検討する。部位のスケールは，a)全体を包括する形 態, b)架構（柱・梁等）の構成に基づく凹凸，c)開口部周りの凹 凸, d)躯体への付設部位，e)表面のテクスチャの 5 段階に分ける。

これらのうち，a〜 cについては，日射や天空への放射によ る加熱・冷却効果が表面温度に反映される要素として無視でき ない。dの付設部位には，手摺・屋外階段・照明装固や室外機等 が挙げられる。これらのうち，総表面稅の大きい手摺。屋外階 段, 面積は小さいが表面温度の大きい照明装置や室外機は考虚 する。e の要素における表面のテクスチャは, 本報は考慮しな い。波形スレート等に対しては考慮すべきだが，本報はそのよ うな部位がなかったためである。よって本報では，建物の外表 面を $\mathrm{a} \sim \mathrm{c}$ 及び $\mathrm{d}$ における手すり。屋外階段・照明装置まで扱 う。なお，表面積は縮尺 100 分の 1 の設計図面より算出した。測 定対象とする外表面の総面稳はN 建物（5階南立面）で $721 \mathrm{~m}^{2}$, $\mathrm{F}$ 建物（全面）で $649 \mathrm{~m}^{2}$ であった。

\section{2. 各部位の表面温度抽出方法}

各部位の材料や形態等と外表面温度との関係を検討するため, まずはじめに，特定の部位毎に温度を抽出した。建物外表面の 部位への分割は材料や形態の逗いに基づいて行った。抽出する 表面温度は各部位に対応したポリゴン毎の画素值の平均とした。

俯瞰撮影による熱画像からの表面温度抽出方法を以下に示す。

1) 熱画像の収録時に生じる広角レンズの歪み, 走㿽による歪 みを補正する。

2）熱画像に写された建物を，各部位に対応したポリゴンで分 割し，表面温度を抽出するためのレイヤーを作成する。

3） 2 で作成したレイヤーを俯瞰撮影した第画像に重ね，各部 位の画素值を平均して抽出し，表面温度とする。

俯瞰撮影した熱画像の空間分解能を下回る大きさであったり， 死角で見えない部位の表面温度は，移動計測で得た熱画像から 部位をポリゴンで囲み，その中の平均温度を用いる。表面温度 を得るために分割した部位の総数は，N建物で185個，F建物で 182 個である。図 10 に各部位の温度を抽出するために用いたレ イヤーを示す。

\section{3. 建物外表面温度の日変化}

図11に建物の各部位における表面温度の外気温との差の日变 化を示す。a・bはN建物，c。d はF 建物における計測值であ る。俯瞰撮影された熱画像に基づいているため，建物の全表面 を対象としていない。外界気象条件や建物の条件が表面温度に 比較的反映されやすい立面として，N建物は南面， $\mathrm{F}$ 建物は南。 西・屋根面の值を表している。

\section{（イ） N建物における外表面温度の日変化}

方位や部位は限られているが，夏享は冬と比べると全ての 部位で外気温との差が極めて小さい。外廊下のある壁面の值は, 


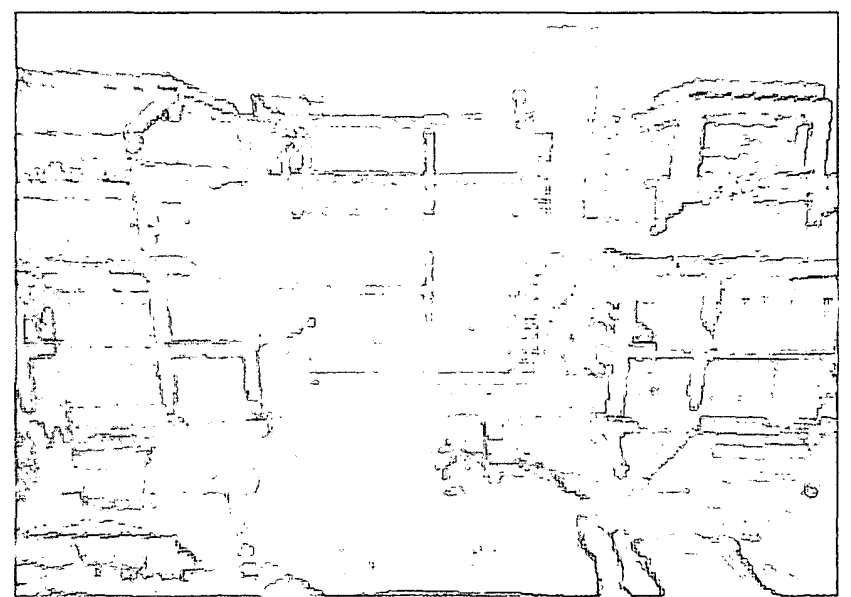

(a) 夏 $\mathrm{R}(27,42) \quad \mathrm{G}(28,32)$ B $(24,29)$

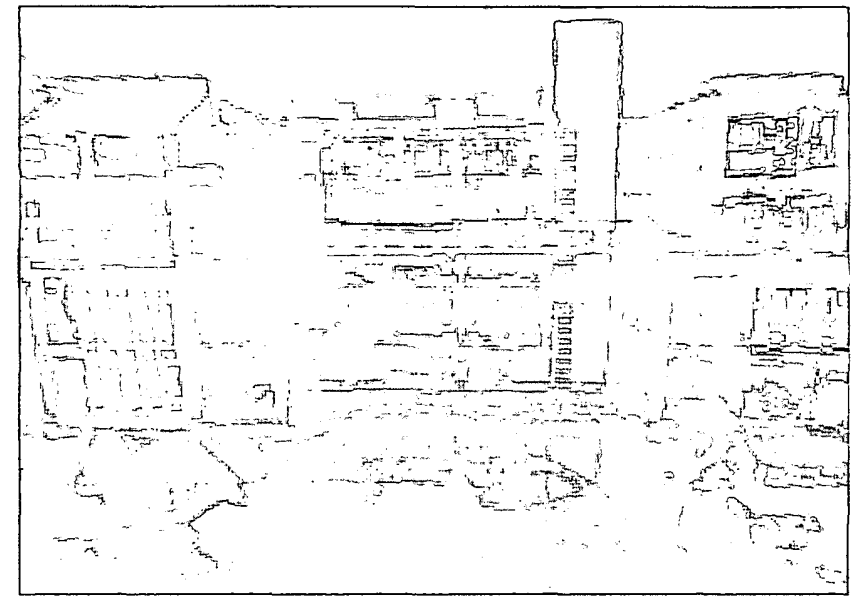

(b) 冬 $\mathrm{R}(7,31) \quad \mathrm{G}(7,15) \quad \mathrm{B}(1,9)$

図 7 N 建物のマルチテンポラル熱画像（括弧内は表示温度の最小・最大值）

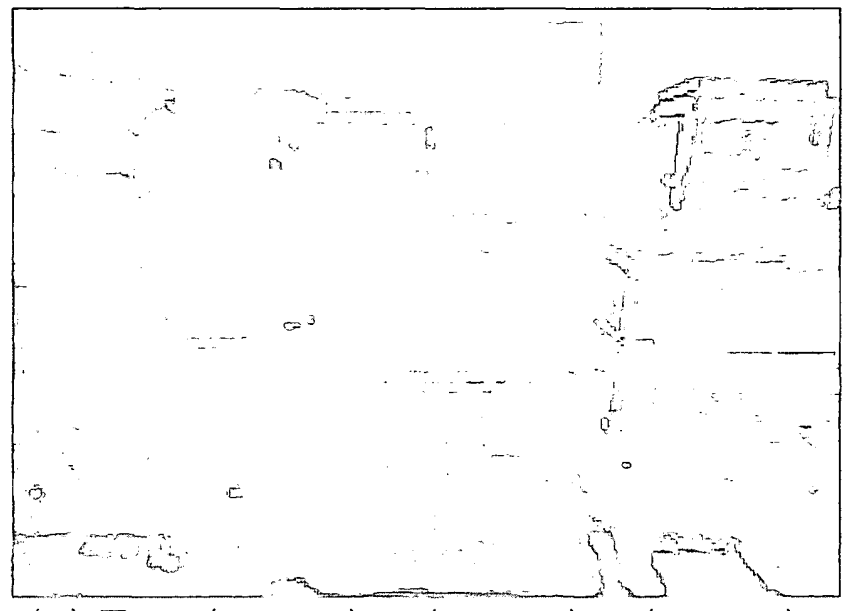

(a) 夏 $\mathrm{R}(24,33,42) \mathrm{G}(28,31,34)$ B $(24,27,30)$

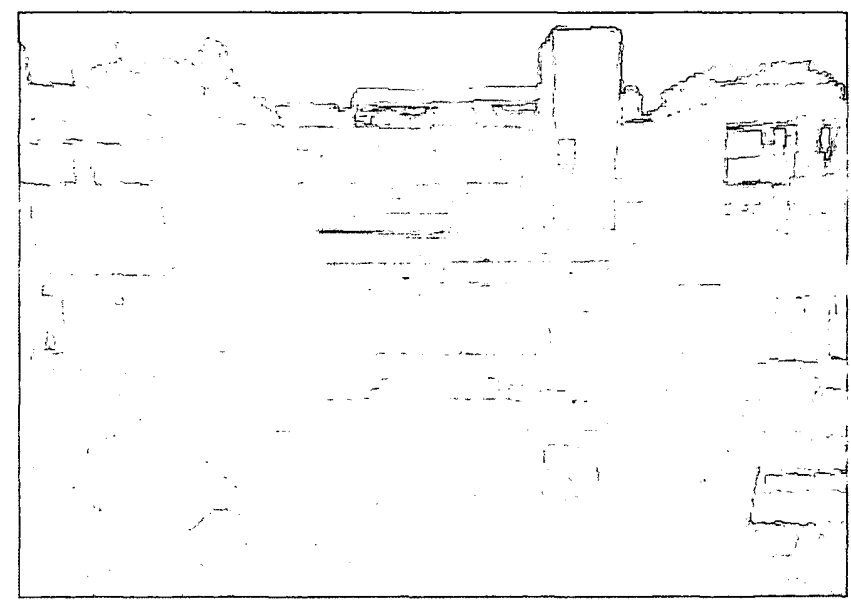

(b) 冬 $R(-9,11,31) \quad G(3,9,15) \quad B(-5,2,9)$

図 8 気温を中央值とした $\mathrm{N}$ 建物のマルチテンポラル熱画像（括弧内は表示温度の最小・中央・最大值）

(a) 夏 $R(18,32,46) \quad G(23,29,35)$ B $(20,24,28)$

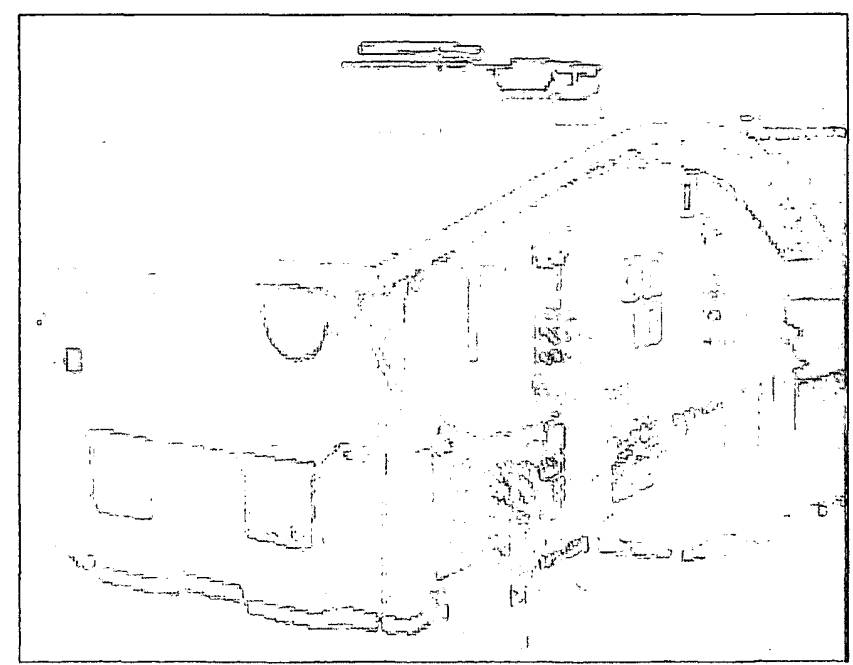

(b) 冬 $R(-11,6,23)$ G $(-1,3,7)$ B $(-2,2,6)$

図 9 気温を中央值とした $F$ 建物のマルチテンポラル熱画像（括弧内は表示温度の最小・中央・最大值）

夏冬

R 12:00 12:00

G 19:00 18:00

B 5:00 6:00
※図 8・9におけるカラースケール

各季節と時刻を左図のように割り当 て，各R GBの温度表示範囲を決定する。 更に，各時刻の気温を中央值とし，各 R G B の温度範囲を表す。単位ぱ Cであ る。右図に打いて十は放熱側を，一は吸 熱側を表す。（注 2)

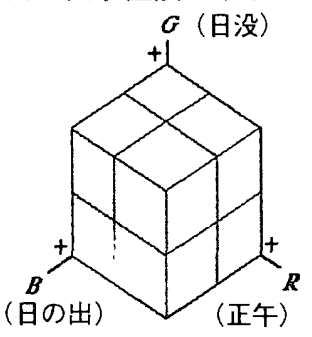

(正午）（日の出）

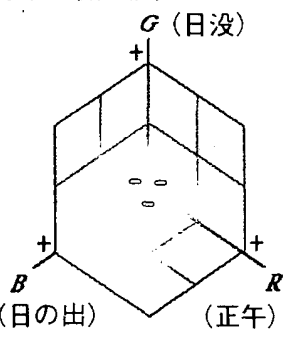




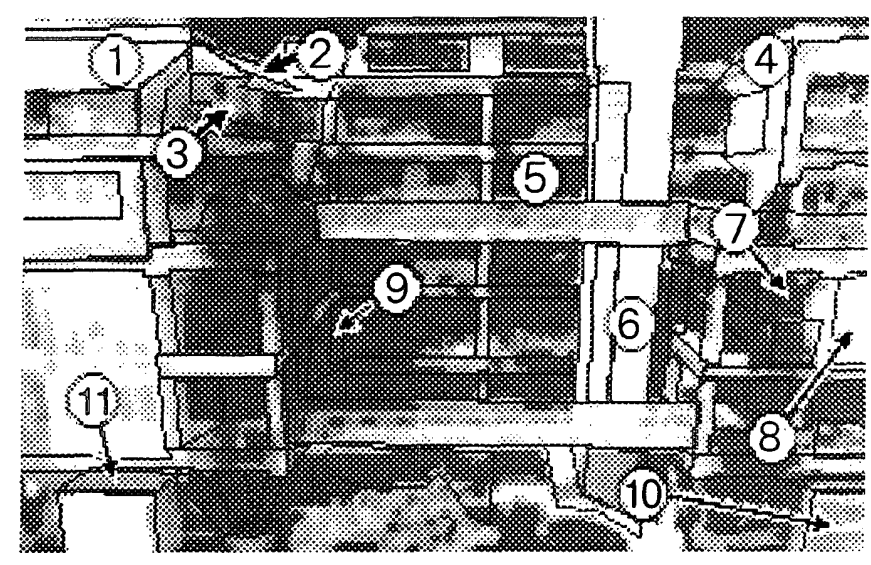

(a) N 建物

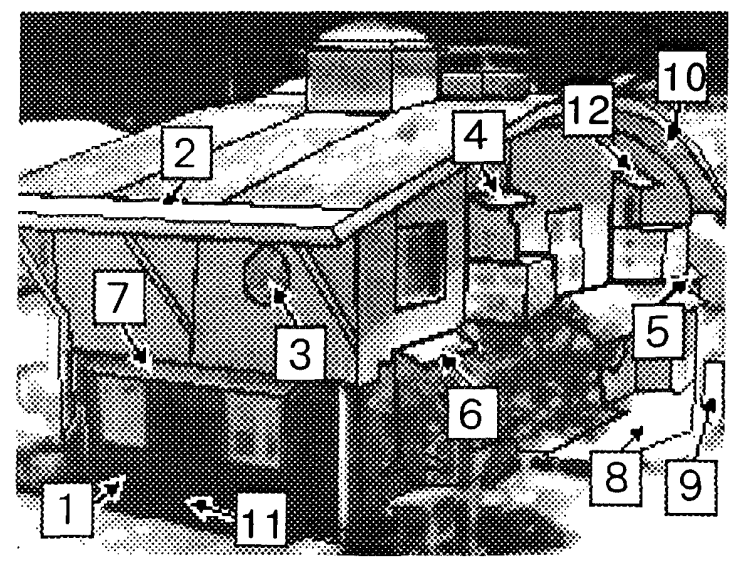

(b) F 建物

図10 熱画像上に示した部位毎の表面温度を得るための主なレイヤー （図中の番号は同じ建物において図11の番号に対忍）

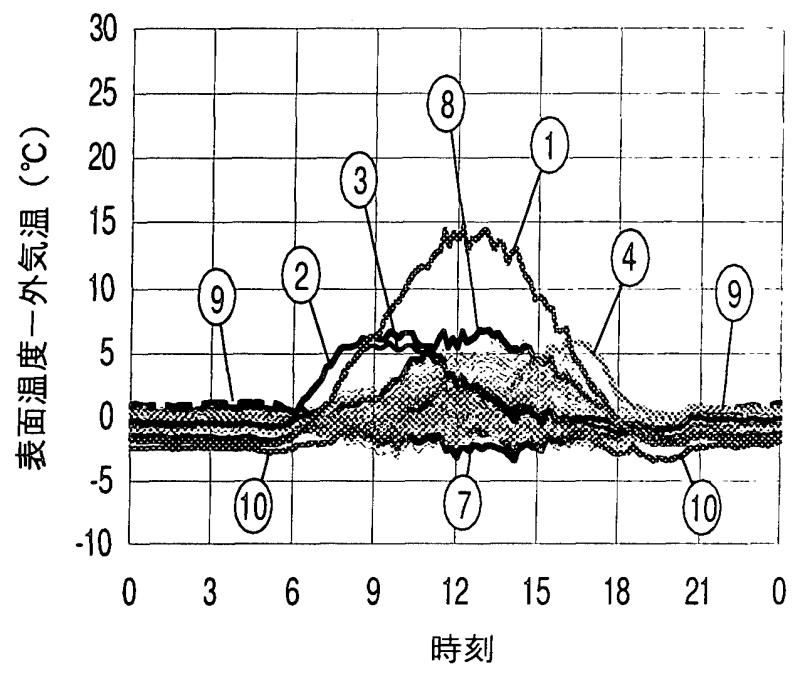

（a） N建物一夏季

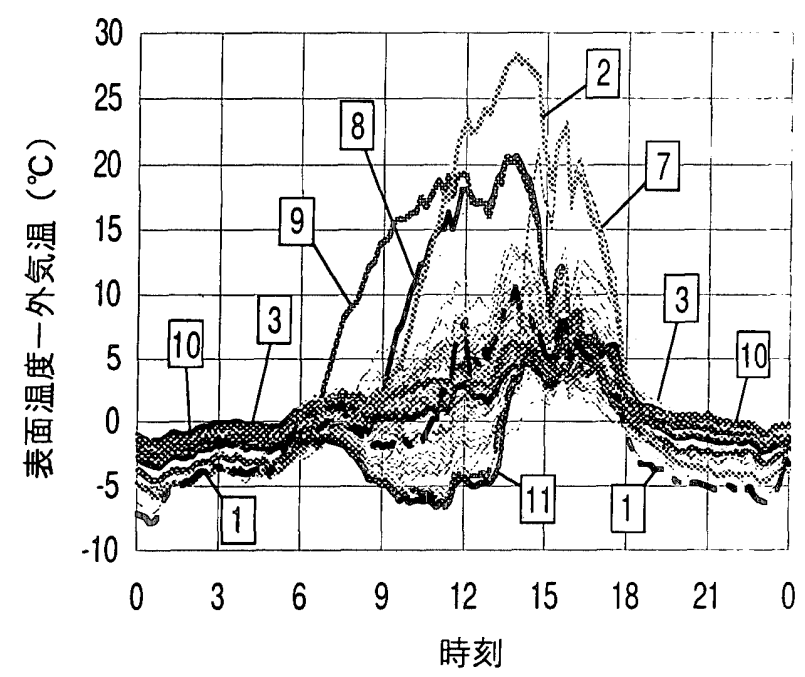

（c） F建物一夏季

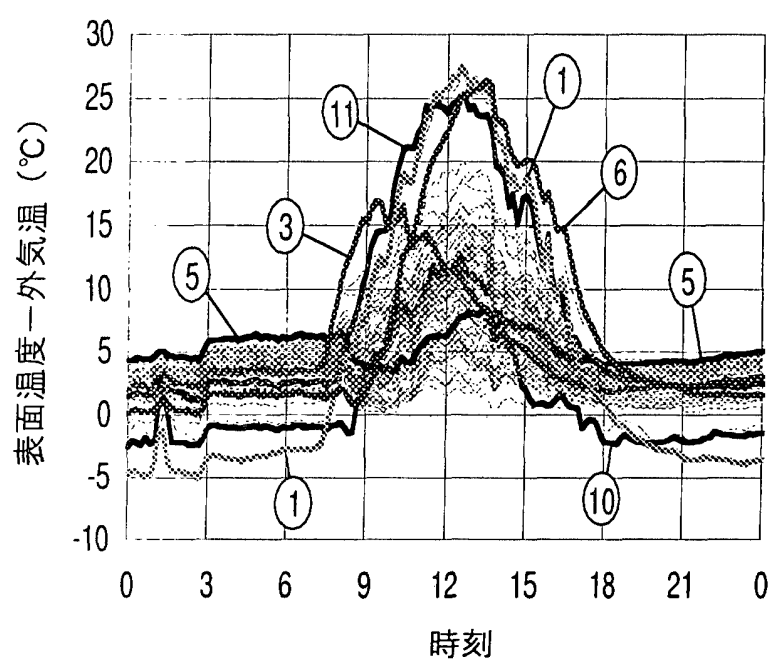

(b) $N$ 建物一冬季

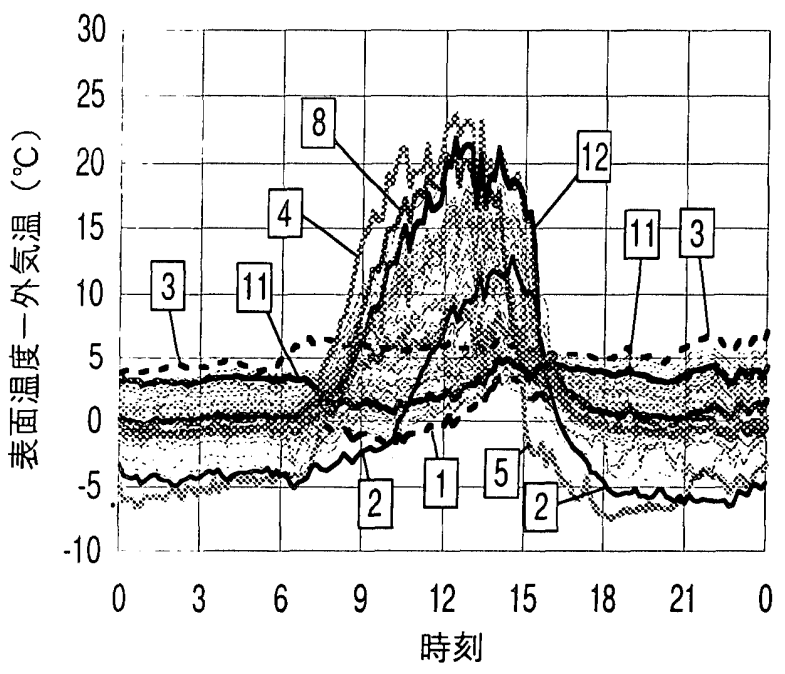

(d) F 建物一冬季

図11建物の各部位における" 表面温度一外気温"の日変化 （図中の各番号は図10の各番号に対応） 
外廊下が直達日射を遮るため, 日中でも土 $2^{\circ} \mathrm{C}$ 以内におさまっ た。夜間はほとんど全ての部位がさ $1^{\circ} \mathrm{C}$ 以内であった。

冬季は直達日射が外廊下内の外壁面まで到達し, 室内は終日 暖房運転もしていたため, ほとんど全ての部位の表面温度が終 日気温より高く, その差は最大で夜間に $5{ }^{\circ} \mathrm{C}$, 昼閒には $25^{\circ} \mathrm{C}$ 以 上であった。

(口) F建物における外表面温度の日変化

方位・部位の対象範囲が広いので, N建物と比べて変動幅が大 きいのが特徴である。夏季は日中の午前に直達日射の当たらな い西面 1 階の漆喰壁や基礎部分の表面温度が外気温より $7^{\circ} \mathrm{C}$ ほ ど低く, 午後になると全部位が外気温より高くなった。夜間に は壁面の熱容量が小さいことが反映され，全ての面が外気温よ り低くなった。

冬季も夏季と同様, 午後に全ての部位が外気温より高くなっ

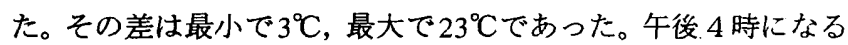
と， $\mathrm{F}$ 建物の南側に位置するオフィスビルの日影となり，全て の部位が 5 時までには外気温との差が $5{ }^{\circ} \mathrm{C}$ 以下になるまで泠却 された。夏季の夜間に外気温以下だった基礎部分や開口部周辺 は，暖房の影響により，冬季の夜間には常に外気温より $5^{\circ} \mathrm{C}$ 程 高かった。

\section{5. 建物の全表面からの顕熱流量}

\section{1. 顕熱流量の算出方法}

熱画像より得た各部位の表面温度と，設計図面より得た面積 をもとに， $\mathrm{N}$ 建物の 5 階における全表面及び $\mathrm{F}$ 建物全体の全表 面からの顕熱流量を求めた。対流熱伝達率及び外気温には全て の部位に対して一定值を適用した。本報での解析対象は比較的 弱風の条件下にあったため, 対流熱伝達率の誤差の影響が相対 的に小さく，上記の仮定の下でもある程度の考察は可能とした。 対流熱伝達率の算出には, 屋上風速とユルゲスの式を用いてい る。すなわち, 顕熱流量の算出結果は各部位毎の局所熱伝達率
を考慮していない。実際の建物の外表面における対流熱伝達率 には分布が存在するが，現在の技術ではそれを計測することは 不可能なため, 今後の重要な研究課題の一つである。

図 12にN建物, 図13に F 建物のそれぞれ夏季及び冬季におけ る顕熱流量の日変化を示寸。図中の凡例は，前述の細かく分割 した部位をそれぞれのカテゴリーで類型化した結果であり，各 部位ごとに算出した顕熱流量はカテゴリーごとに積算した値で 示している。図12における付設部位は手摺を含む屋外階段の全 表面を示している。グラフ下部の「 $\alpha=」 に$ 続く数值は, 各時刻 に対して用いられた対流熱伝達率（W/m² K）である。

\section{2. 顕熱流量の日変化に対する考察}

前章までの結果で示したとおり， $\mathrm{N}$ 建物では，主に立体外廊 下による日射の調節・及び冬季の暖房運転の影響が，外表面か らり放熱状況に大きく影響している。F建物では，主に外表面 が全体的に熱容量の小さい材料で構成されていること，冬季の 暖房運転の影響が放熱状況に大きく影響している。本章ではこ れらの要素を中心に, 各建物からの顕熱流量の日変化との関連 性を考察する。

\section{（イ） N建物の5 階南立面からの顕熱流量}

5 階壁面は立体外廊下内にあるため, 夏季の高い高度からの 直達日射をほとんど受けず, 顕熱流量は吸熱方向に $1 \mathrm{~kW}$ であっ た。立体外廊下による日射遮蔽のない 6 階床面が $8 \mathrm{~kW}$ も放熱 量であった事と対照的である。冬季は低い高度からの直達日射 を受けて受熱日射量が増大し, 更に䁔房運転の影響も加わった 結果，終日にわたって全表面から放熟していた。その量は夏季 の10倍以上もあり，正午には 5 階壁面からの顕熱流量だけで,夏 季の全放熱量を上回る $25 \mathrm{~kW}$ となった。立体外廊下による直達日 射の調節機能が非常に効果的に働いている。しかし，日の出時 の顕熱流量が夏・冬とも正午の半分近くにも達している。実際, 梁夜から早朝にかけての立体外廊下内部は, 体感的にもかなり 蒸し暑くなっていた。日の出時の屋上風速が約 $1 \mathrm{~m} / \mathrm{s}$ と弱風であ

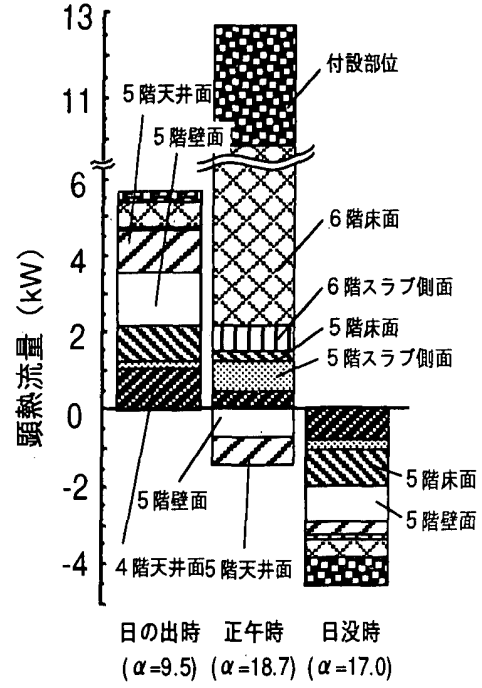

(a) 夏季

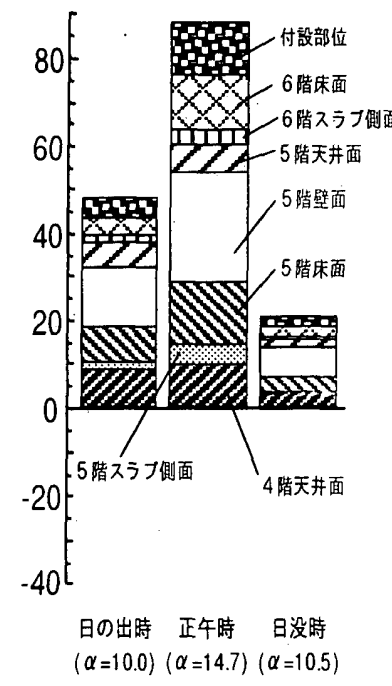

(b) 冬季

図12N建物からの顕熱流量

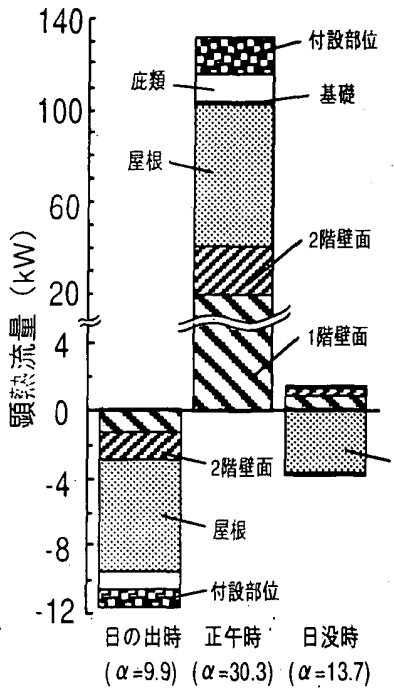

(a) 夏季

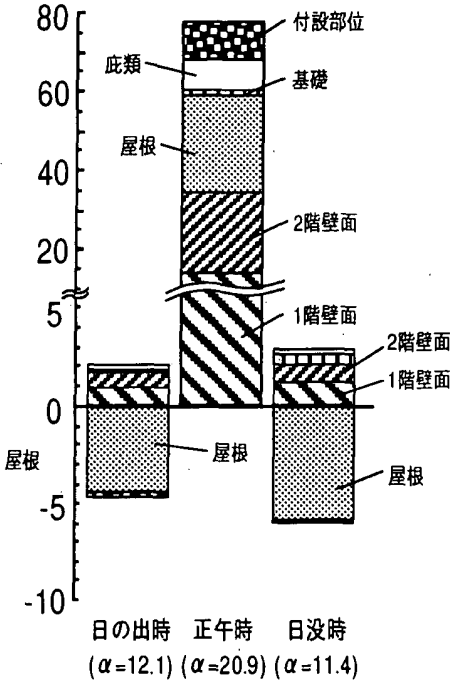

(b) 冬季
図13F建物からの顕熱流量 
ることや，立体外廊下が天空への放射による冷却を妨げている ことが要因と言える。

是本の日没時に全部位が吸熱に転じているが,その理由は, 外 気温が外表面温度よりも緩やかに低下していたためである。し かし，移動計測直後の午後 8 時頃から外気温が大きく低下し，一 部の部位は放熱側に転じた。なお，外部の照明器具からの顕熱 流量は全体の $2 \%$ に渵たないため，グラフからは除いた。

（ロ） $\mathrm{F}$ 建物の全表面からの顕熱流量

全体的に熟容量の小さい建物であることが顕熱流量に反映さ れている。旦季の日の出時には夜間の天空への放射冷却により， 全ての部位からの䫓熱流量が吸熱方向であったが, 正午には直 達日射を受けて全て放熱側に転じた。冬季は暖房の影響で，3 つの時間帯とも付設部位と屋根面を除く全ての部位から放熱し ていた。両本節のどの時間帯においても, 放熱・吸熱量ともに屋 根面の占める割合が一番大きい。夏季と冬季を比較すると, 夏 季の日の出時は，終日暧房薑転の行われた冬季の日の出時と比 べ３倍もの吸熱量であり，両季節の日の出・日没時の中で最大 值を示した。是季の正午には日射の影響で放熱量が冬季の正午 の 1.5 倍になった。

\section{6. まと的}

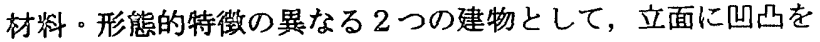
有する $R C$ 造建物 (N建物) と, 比較的単純な形態の木造建物 $(\mathrm{F}$ 建物）を選定し，赤外線放射カメラを用いて表面温度分布非1を 計測した。N建物については 5 階の南立面，F建物については 全表面を対像に, 夏季と冬季における顕熱流量の日変化を求め, 立面の凹凸や材料の熟容量, 暧房運転の有無等が顕熱流量に与 える影䍌を考察した。

本報は特定の建物を対象としており，気象条件も夏季と冬季 の昖天日に限られているが，実測データをもとに建物の全外表 面からの顕熟流量を詳細に求めた初めての試みであり, 都市気 候の数值計算モデルに組み込むべき建物モデルを検討する上で の基碳瓷料を得ることができた。今後は更に計測を重ね，資料 の蓄穦をしていきたい。

おわりにあたり，N建物の実測には，大阪ガス（株）の勝瀬進 氏，F建物の奏測には岩村アトリエの岩村和夫氏・(株)いわき ニュータウンセンターの方々，赫線放射カメラの使用につい ては日本電気三栄（株）の松永徹志氏の協力を得たことをここ に記して樑謝の意を表す。

\section{注1）熟画像の取り报いについて}

效画䐄で得られる温度は放射温度であるが, 表面温度への変 构は現時点の研究段階では图嚾である。そこで放射率が極めて 小さい部位を除き，放射温度をそのまま表面温度とみなして取 り颃う。伤瞰撮影では遠隔から空間分解能の高い画像を得る必 要があったため, 赤外線放射カメラの測定波長帯は大気の空領 域である $8 \sim 12 \mu \mathrm{m}$ 帯を用いた。移動計測では, ガラスの放射温 度を主に計測するため, ガラスの単色放射率が 0.95 以上となる 6〜8 4 m帯のカメラを用いた。この波長帯は水蒸気吸収帯である が, 数 $\mathrm{m}$ の近距噰から計測したため大気補正は不要とみなした。
熱画像によるガラスの放射温度計測, 及び赤外線放射カメラの 仕様の詳細については文献 6 を参照のこと。

注 2 ） R（Ｂの加算混合による画像について

合成画像上の色光 $C$ は，各色 $R \cdot G \cdot B$ の刺激量を表す $r^{\circ} g$ 。 $b$ を用いて $C=r R+g G+b B$ と表すことができる。このことから 3 原 色を 3 軸とする直交座標（色度座標）によって色 $C$ を表現する と，色の違いはベクトルの方向の違いで表現され，ベクトルの 長さは色光の明るさに対応する。なお，気温を基準に合成した 画像では, 刺激量の中央を境に $r \cdot g \circ b$ が大きくなると放熱側 に, 小さくなると吸熱側となり，1日を通した建物からの熱の移 動方向を一枚の画像から知ることができる。

注 3) 本論文は文献 $7 \cdot 8 \cdot 9$ に発表した内容を, 加箪・修正し たものである。

付表 1) $\mathrm{N}$ 建物の主な構成材料（数值の単位は mm）

\begin{tabular}{|c|c|}
\hline 構造体 & コンクリート打ち放し（立体外廊下スラブ厚 180） \\
\hline 壁仕上 & アスロックタイル又はステンレスパネル \\
\hline 恎下地 & A L C 板厚 100 又はアスロック厚 60 \\
\hline 断熱材 & $\begin{array}{l}\text { グラスウール厚 } 75 \\
\text { 及び発泡ウレタンフォーム厚 } 50\end{array}$ \\
\hline 空 & $\begin{array}{l}\text { 三重ガラス（ガラス厚 } 3, \text { 空気層厚 12/6), } \\
\text { アルミサッシ }\end{array}$ \\
\hline
\end{tabular}

付表 2） $\mathrm{F}$ 建物の主な構成材料（数值の単位は mm）

屋根 芝生植裁, 盛り土厚 $70 \sim 80$, 保水・排水用パネル厚 50 ，杉縁甲板厚 38

外壁仕上 杉縁甲板厚 15 又は㳢喰 +合板厚 12

外壁下地 通気層厚 16 及び通気シージングボード厚 12

断熱材

空 ガラス厚 3, アルミサッシ

引用文献

1) Akinaru Iino and Akira Hoyano: "Development of a method to predict the heat island potential using remote sensing and GIS data," Encrgy \& Building, 23, pp.199-205, 1996

2 ）梅干野㫤, 古賀和博他：サイドルッキング航空機 MSS デー 夕を用いた丘陵開発地域の顕熱流量の解析, 日本建築学会計画 系論文報告集，第 462 号, pp49-58，1994年 8 月

3) 梅干野泉, 飯野秋成他 : サイドルッキング航空機 MSS デー タを用いた丘陵開発地域のヒートアイランドポテンシャルの計 量及び土地被覆との関係の検討，日本建築学会計画系論文報告 集, 第 471 号, pp29-37, 1995 年 5 月

4 ) 斉藤平蔵: 相当外気温度, 日本建築学会環境工学委員会熱分 科会第 8 回熱シンポジウム, pp29-36, 1978 年

5 ) 中嶋まどか, 永田明寛他: 建物外表面の対流熱伝達率に関す 万研究, 日本建築学会大会学術講演梗概集, 環境工学II, pp157$15 \%, 1995$ 年 8 月

6 ）梅千野㫤, 内山一雄他: 多重分光熱画像を用いた建築外部空 間における放射温度計測に関する基磍的研究, 日本建筑学会計 画系論文報告集，第459号，pp17-25，1994年 5 月

7) 梅干野沓, 浅野耕一他: 熱画像を用いた凹凸を有する建物立 面の放射温度分布特性の解析，日本リモートセンシング学会

第 19 回学術講演会論文集, pp227-230, 1995 年 11 月

8 ) 金丸㓮久, 梅干野鼠他: 立体外廊下等の凹凸を有する建物立面 における夏冬の顕熱, 日本建築学会大会学術講演梗概焦, 環境工 学 $11, p p 127-128,1996$ 年 9 月

9) 梅干野晁, 金丸剛久他 : マルチテンポラル熱画像を用いた $\mathrm{RC}$ 造建物外表面からの顕熱, 日本りモートセンシング学会 第 21 回学術講演会論文集, pp181-184, 1996 年 11 月

(1997年1月10日原稿受理, 1997 年 5 月15日採用決定) 